\title{
The role of air-sea exchange in the marine nitrogen cycle
}

\section{T. Jickells}

Laboratory for Global Marine and Atmospheric Chemistry, School of Environmental Sciences, University of East Anglia, Norwich NR4 7TJ, UK

Received: 23 December 2005 - Published in Biogeosciences Discuss.: 23 February 2006

Revised: 11 May 2006 - Accepted: 31 May 2006 - Published: 29 June 2006

\begin{abstract}
This contribution to the Spot-On volume considers the magnitude and composition of atmospheric nitrogen inputs to the oceans and then goes on to consider the impacts of these inputs. Effects in open ocean and coastal areas are probably different. Offshore atmospheric inputs may produce a small enhancement of overall ocean productivity and hence $\mathrm{CO}_{2}$ drawdown. In coastal waters atmospheric inputs contribute significantly to overall eutrophication pressure, but evidence that they trigger algal blooms is limited. Management of atmospheric inputs to coastal waters to mitigate eutrophication pressures requires that emissions be managed over a wide area reflecting the efficient long range transport of atmospheric nitrogen. Strategies for management of oxidised and reduced nitrogen deposition will be different reflecting their different rates of deposition.
\end{abstract}

\section{Introduction}

Atmospheric inputs represent a significant component of the global nitrogen cycle and provide a relatively fast and efficient mechanism by which nitrogen released in one component of the Earth system can impact areas remote from the source regions. In this short article I will attempt to summarise our knowledge of the nature, cycling and magnitude of atmospheric nitrogen inputs to the oceans and then go on to speculate on the effects of these inputs. In considering effects it is convenient to consider open ocean and coastal systems separately.

Correspondence to: T. Jickells

(t.jickells@uea.ac.uk)

\section{Atmospheric deposition to the oceans}

\subsection{Sources}

Atmospheric nitrogen is traditionally considered in terms of two main components, oxidised and reduced nitrogen. The chemical behaviour of these components relevant to their atmospheric inputs is described very briefly here. More extensive discussions are available in Paerl et al. (2002); Raes et al. (2000); Spokes and Jickells (2005) or in standard texts such as Seinfeld and Pandis (1998). Oxidised nitrogen is dominated by emissions of $\mathrm{NO}$ and $\mathrm{NO}_{2}$ (usually referred to as $\mathrm{NO}_{\mathrm{x}}$ since they can interchange rather easily) which react relatively quickly (hours to days) to form nitric acid which can then react to form nitrate aerosol. Reduced nitrogen emissions are dominated by $\mathrm{NH}_{3}$ gas and this gas is a major base in the atmosphere and reacts rapidly and sometimes reversibly with acids such as $\mathrm{HCl}, \mathrm{H}_{2} \mathrm{SO}_{4}$ and $\mathrm{HNO}_{3}$. In addition there are components such as relatively inert $\mathrm{N}_{2}$ gas, the main gas in the atmosphere, and the long lived trace gas $\mathrm{N}_{2} \mathrm{O}$ which will be covered by others in this symposium volume. Recently it has become clear that organic nitrogen (Table 2) is also important and will be discussed later.

Table 1 provides an estimate of global nitrogen fluxes, both natural and anthropogenic. Such compilations are necessarily best estimates and exclude sources that may be important locally or episodically. For instance Uematsu et al. (2004) and Huebert et al. (1999) recently noted the importance of nitrogen emissions associated with volcanic activity. The global nitrogen cycle has been massively perturbed by human activity (Galloway et al., 2004) and this includes the atmospheric component. Not only have total atmospheric nitrogen emissions changed over the last few hundred years associated with a doubling of overall global nitrogen fluxes (Galloway et al., 1995) but the nature of sources continue to change as global patterns of agriculture and industry evolve (e.g. Galloway et al., 2004; Fowler et al., 2004; Paerl et al.,

Published by Copernicus GmbH on behalf of the European Geosciences Union. 
Table 1. Atmospheric emissions of fixed nitrogen $199310^{12}$ moles $\mathrm{N} \mathrm{yr}^{-1}$ (based on Galloway et al., 2004).

\begin{tabular}{lcc}
\hline Activity & $\mathrm{NO}_{\mathrm{x}}$ & $\mathrm{NH}_{3}$ \\
\hline Anthropogenic & & \\
Biomass Burning* & 0.5 & 0.6 \\
Agricultural Activity & 0.2 & 2.8 \\
Fossil Fuel Combustion & 1.5 & 0.01 \\
Industry & 0.5 & 0.2 \\
& & \\
Natural & & \\
Soils, vegetation and animals & 0.2 & 0.3 \\
Lightening & 0.4 & - \\
Natural fires** & 0.06 & 0.06 \\
Stratosphere exchange & 0.04 & 0.04 \\
Ocean exchange & - & 0.4 \\
Total & 3.4 & 4.5 \\
\hline
\end{tabular}

* Some of the tropical biomass burning included here could be natural.

** Under "natural fires" only high latitude forest fires are included.

2002). Table 1 presents estimates of the $\mathrm{NO}_{\mathrm{x}}$ and $\mathrm{NH}_{3}$ atmospheric emission sources, and emphasises that about $80 \%$ of current emissions are anthropogenic. Anthropogenic $\mathrm{NO}_{\mathrm{x}}$ emissions are dominated by those associated with fossil fuel combustion while anthropogenic $\mathrm{NH}_{3}$ emissions are associated with agricultural activity, particularly the handling of waste from intensive animal husbandry. The emission pattern is dominated by sources in highly populated and/or intensively farmed regions particularly in the Northern Hemisphere.

\subsection{Reactions}

As noted above, $\mathrm{NO}_{\mathrm{x}}$ is oxidised on a time scale of hours to days depending on atmospheric conditions to $\mathrm{HNO}_{3}$ which is then reactive with other gases and aerosols and can also be rapidly removed by deposition. Ammonia gas is also highly reactive in the gas phase and does not require an oxidation step prior to reaction. The result of these differences is that ammonia tends to be deposited closer to sources with $\mathrm{NO}_{\mathrm{x}}$ only undergoing deposition after oxidation (Spokes and Jickells, 2005). For instance it is estimated that $71 \%$ of $\mathrm{UK} \mathrm{NO}_{\mathrm{x}}$ emissions are exported to the North Sea and beyond, while only $25 \%$ of ammonia emissions are exported (NEGTAP, 2001). This pattern is also seen in the eastern USA, but differences between oxidised and reduced nitrogen behaviour are less. This may reflect differences in emission patterns or climatology (Paerl et al., 2002), stressing the importance of dealing with different regions individually. This difference in behaviour between oxidised and reduced nitrogen has im-
Table 2. Aerosol water soluble organic nitrogen concentrations in aerosols at some selected locations.

\begin{tabular}{lcl}
\hline Location & $\begin{array}{c}\text { Concentration } \\
\mathrm{nmol} \mathrm{m}^{-3}\end{array}$ & \\
\hline Delaware coast & 6.9 & Russell et al. (2003) \\
Amazonia wet season & 3.5 & Mace et al. (2003a) \\
Dry (burning) season & 61 & Mace et al. (2003a) \\
Mediterranean & 29 & Mace et al. (2003b) \\
Tasmania ocean sector & 0.95 & Mace et al. (2003c) \\
land sector & 3.6 & Mace et al. (2003c) \\
Hawaii ocean sector & 3.3 & Cornell et al. (2001) \\
land sector & 28.5 & Cornell et al. (2001) \\
\hline
\end{tabular}

portant implications for management strategies (see later).

Over land the primary reactions controlling the behaviour of oxidised and reduced nitrogen are acid base reactions forming aerosols from gas phase species. Such reactions result in the formation of fine ( $<1 \mu \mathrm{m}$ diameter) aerosols (Raes et al., 2000). Some of the resulting aerosol species are semivolatile and hence ammonium nitrate and ammonium chloride can dissociate to their component gases as ambient concentrations of those gases fall during transport and mixing. In certain environments such as near deserts, alkaline soil dust aerosol makes an important contribution to the aerosol, and in such environments these particles will also react with acids. Soil dust aerosol is usually formed by mechanical processes in arid areas and results in coarser aerosol particles $(>1 \mu \mathrm{m})$. In addition when continental air masses are mixed with seasalt aerosols near the coast there is a reaction between seasalt and nitric acid:

$\mathrm{HNO}_{3}+\mathrm{NaCl} \rightarrow \mathrm{NaNO}_{3}+\mathrm{HCl}$.

Seasalt is formed mechanically which also creates coarser aerosol particles, and hence this reaction shifts nitrate from fine mode to coarse mode. It also releases $\mathrm{HCl}$ which can then liberate free halogen radicals which can influence ozone cycling (e.g. Ayers et al., 1999). The importance of these reactions of nitric acid with dust and seasalt is that they serve to move the nitrate onto coarser aerosol particles. Atmospheric deposition rates increase rapidly with particle size. Kane et al. (1994) and Russell et al. (2003) have estimated that the reaction with seasalt increases deposition rates of nitrate in the marine environment by increasing particle size and deposition rates and this offsets the effects of the removal of highly reactive nitric acid (Pryor and Sørenson, 2002).

\subsection{Deposition}

Atmospheric deposition occurs by wet and dry deposition, the latter including both dry deposition of particles and gases. Gas deposition depends on concentration gradients across the air-sea interface and the equilibrium distribution between the 
phases (Henry's Law constant). Nitric acid concentrations in seawater are extremely low so deposition is a one way process, and nitric acid is rapidly and efficiently deposited (Pryor and Sørenson, 2002). For ammonia the situation is more complex as discussed below. Paerl et al. (2002) suggest that nitric acid dominates over nitrate, and ammonium over ammonia in both the eastern USA and Northern Europe, possibly because of efficient reaction of ammonia with sulphuric acid which is usually the dominant acid in the atmosphere. Norman and Leck (2005) find ammonia and ammonium concentrations to be generally similar with a slight dominance of ammonium in a large scale study covering much of the Atlantic Ocean. Reactions of seasalt with nitric acid mean that nitrate probably dominates over nitric acid in the remote marine boundary layer (Keene et al., 1998), although the distinction between these species can be difficult to achieve with many sampling strategies.

For all the other species of interest here we are essentially considering wet and dry aerosol deposition, a process whose rate increases rapidly and non-linearly with aerosol particle size. Hence the importance of reactions of acid species with seasalt and dust as discussed above for creating coarse mode nitrate in the marine atmosphere as opposed to a fine mode dominance in the terrestrial atmosphere. There is also now evidence of some coarse mode ammonium in the marine atmosphere (Spokes and Jickells, 2005).

The relative importance of wet and dry deposition obviously varies greatly on short time scales since rainfall is episodic and varies spatially on longer time scales with global rainfall patterns. Relative proportions of wet and dry deposition from many campaigns lasting weeks have been reported, but these are still subject to the vagaries of the weather. Variations in precipitation type (e.g. frontal, orographic, thunderstorm, snow rain etc) and associated height and extent of scavenging of atmospheric gases and aerosols will also affect deposition, though we cannot describe these effects quantitatively at this time. Long term average wet deposition estimates are available for some sites though these are usually only for inorganic components, and these suggest that wet deposition dominates (Table 3). Since wet deposition is dominant and intrinsically episodic, and because atmospheric circulations such as frontal system can sometimes concentrate atmospheric contaminants in wet deposition, it follows that atmospheric deposition is episodic, often highly so (e.g. Spokes and Jickells, 2005), an issue of importance when assessing impacts.

\subsection{Fluxes to the oceans}

Dentener has used model simulations to estimate atmospheric $\mathrm{N}$ fluxes to the oceans in general and to different ocean basins (Galloway et al., 2004). The model simulations allow estimates of past fluxes as well, illustrating the changing deposition pattern with time. The model estimates are very similar to early estimates of Duce et al. (1991) which
Table 3. Percentage of total deposition which is wet from a variety of long time series measurements.

\begin{tabular}{lcl}
\hline Site & $\begin{array}{c}\text { Wet } \\
\text { Deposition* }\end{array}$ & Reference \\
\hline 40 US East Coast & & \\
Watersheds & $61 \%$ & Meyers et al. (2001) \\
Kattegat & $79 \%$ & Carstenson et al. (2005) \\
Southen North Sea & $55 \%$ & Chester et al. (1994) \\
World Oceans & $71 \%$ & Duce et al. (1991) \\
\hline
\end{tabular}

*only Southen North Sea estimate includes organic nitrogen

were based on extrapolation of data from measured sites across the oceans. The agreement of these two approaches gives confidence in the overall fluxes, although in model development there is inevitably a process of calibration against field data so agreement between the two is not a wholly complete test of the models. Galloway et al. (2004) report the overall nitrogen fluxes to the ocean to be $2.4 \times 10^{12}$ moles $\mathrm{yr}^{-1}$ representing about a third of total nitrogen emissions to the atmosphere. This estimate excludes organic nitrogen. Oxidised nitrogen is estimated to dominate total deposition $\left(1.5\right.$ (nitrate) vs. 0.9 (ammonium) $\times 10^{12} \mathrm{~mol} \mathrm{yr}^{-1}$ ) again reflecting the preferential removal of ammonia emissions close to sources compared to emissions (Table 1).

The ammonia fluxes to the oceans are complicated by an internal recycle. In surface seawater ammonium is produced and consumed by marine biological processes. At the $\mathrm{pH}$ of seawater a small percentage of the ammonium is present as dissolved ammonia and this maintains an air-sea exchange equilibrium with atmospheric ammonia gas. This emission cycle has been suggested to be an important climate regulation process via the formation of ammonium sulphate aerosol, the sulphate being derived from marine biogenic emission of DMS (Liss and Galloway, 1993; Bigg et al., 2003; Norman and Leck, 2005). This process is estimated to have resulted in a small net flux of ammonia from sea to land in the pre-industrial period (Galloway et al.,1995). On a global basis this has probably now been reversed (Galloway et al., 2004). Any ammonia emitted from the oceans is probably re-deposited fairly rapidly and hence predominantly in the oceans due to the rapid dry deposition and reactions of ammonia. Hence this cycle is not included in the overall $\mathrm{N}$ fluxes to the ocean above. However, this essentially internal cycle within the nitrogen cycle may still be important in process such as marine aerosol formation and $\mathrm{pH}$ control (Liss and Galloway, 1993; Norman and Leck, 2005). Isotopic evidence suggests that in remote ocean areas far from terrestrial ammonia sources, this marine recycled ammonia may become particularly important (Jickells et al., 2003). This isotopic approach offers a method to correct for any ammonia 
emitted from the oceans present in aerosols within the marine boundary layer.

\subsection{Organic nitrogen}

It is now clear that organic $\mathrm{N}$ represents a significant component of atmospheric $\mathrm{N}$ deposition. Most studies to date have focussed on organic matter that is either soluble in rainwater or easily extracted by water from aerosols (Cornell et al., 2003) but one study also considered insoluble organic $\mathrm{N}$ and noted it to be much more abundant than the soluble organic fraction (Russell et al., 2003). The nature and sources of atmospheric organic nitrogen are largely unknown, and it is undoubtedly composed of a wide range of organic material. Although in some areas some highly biologically labile components such as urea and amino acids appear to be important, much more refractory components such as humic material may also be important (Cornell et al., 2003). In both remote and more contaminated areas the organic nitrogen has an important fine mode aerosol component suggesting it is formed from gas to particle reactions, although a coarse mode from primary sources is also seen. (Cornell et al., 2001; Mace et al., 2003c; Russell et al., 2003). Seitzinger and Sanders (1999) have suggested that a significant fraction of atmospheric organic nitrogen may be bioavailable.

Comparison of results from several studies around the world provide some clues as to sources of the water soluble aerosol organic nitrogen (Table 2). Much higher concentrations appear to be associated with air flows from land, rather than from the oceans, suggesting that terrestrial sources, rather than, for instance, recycled marine organic matter, dominate. Biomass burning may also be important as a source. Existing studies do not identify any simple relationship between organic and inorganic nitrogen in the atmosphere which would be anticipated if the organic material had clear and simple anthropogenic sources. For instance, in sites with relatively high concentrations of nitrate from contaminant sources such as the Delaware coast, organic nitrogen concentrations are not exceptionally high (Russell et al., 2003) and Cape et al. (2004) in an extensive study at 7 sites in the UK and Neff et al. (2002) found no simple relationship to other inorganic nitrogen components. It is therefore not possible to say with any confidence if this organic nitrogen is of predominantly natural or anthropogenic origins. It probably has a mixed origin, and indeed it is perfectly possible that the $\mathrm{C}$ framework may be of natural origin and the $\mathrm{N}$ of anthropogenic origin, reflecting formation by atmospheric reactions. This would be consistent with some of the very limited available $\mathrm{C}$ and $\mathrm{N}$ isotopic data for atmospheric aerosol water soluble organic nitrogen (Kelly et al., 2005).

Although the data base is small, Cornell et al. (2003) review a wide range of individual studies from many different environments which suggest on average organic $\mathrm{N}$ constitutes about $35 \%$ of total atmospheric nitrogen. More recent results are broadly consistent with this value with reported values from remote sites ranging from 17-46\% (Mace et al., 2003a, b, c) and for 7 sites in the UK (rainfall only) 24-40\% (Cape et al., 2004). Neff et al. (2002) also suggest a figure of $30 \%$. Assuming organic nitrogen represents $35 \%$ of total nitrogen deposition, if inorganic atmospheric nitrogen deposition is $2.4 \times 10^{12}$ moles $\mathrm{yr}^{-1}$ the organic component will be an addition $1.3 \times 10^{12}$ moles $\mathrm{yr}^{-1}$, giving a total flux of $3.7 \times 10^{12}$ moles $\mathrm{yr}^{-1}$. Note this assumes scavenging rates and deposition velocities for atmospheric organic and inorganic nitrogen are similar. This can be compared with a total riverine flux $3.4 \times 10^{12}$ moles $\mathrm{yr}^{-1}$ (Galloway et al., 2004). This further emphasises the importance of atmospheric deposition and that reduced, oxidised and organic nitrogen are all of importance in overall atmospheric nitrogen deposition. Furthermore, the budgets for the North Atlantic of Galloway et al. (1996) suggest that fluvial nitrogen inputs to the oceans are denitrified on the shelf and that the shelf region is a sink rather than a source of nitrogen for the open oceans. Their analysis leaves atmospheric inputs and nitrogen fixation as the dominant inputs of nitrogen to the open ocean.

\section{Effects of atmospheric deposition}

Atmospheric inputs are therefore comparable to fluvial inputs and of the same order of magnitude as marine nitrogen fixation, so it is logical to ask what effect this input has on the marine ecosystem. In considering this question it is useful to separate the impact on the open ocean from coastal waters because the latter are subject to high nitrogen loadings in general including atmospheric inputs. It is not possible to consider impacts of nitrogen alone since phytoplankton primary production requires a range of nutrients $-\mathrm{N}, \mathrm{P}, \mathrm{Si}$ and Fe particularly, plus light. Human activity mobilises large amounts of gas phase nitrogen as $\mathrm{NH}_{3}$ and $\mathrm{NO}_{\mathrm{x}}$. Since $\mathrm{P}$ and Si have no significant gas phase components, their atmospheric fluxes are minor and little perturbed by human activity (e.g. Jickells, 1998; Baker et al., 2003, 2006). Iron fluxes are similarly probably little modified by human activity, although desertification may have some impact (Jickells et al., 2005). The effective trapping of fluvial iron within coastal systems means that atmospheric inputs of iron represent a major source of this key nutrient to ocean waters and the absence of this input contributes to the development of highnutrient-low-chlorophyll (HNLC) regions in the oceans such as in the Southern Ocean (Falkowski et al., 1998; Jickells et al., 2005). Thus in assessing atmospheric inputs, the balance of nutrient inputs, in addition to simply the nitrogen inputs, must be considered. The atmosphere is also an important transport route for a wide variety of contaminants to the marine system (Duce et al., 1991) albeit at relatively low levels. The combined effects of nutrient and contaminant addition have never been studied in this context, although we know that small changes in the availability of copper for example 
can have significant effects on phytoplankton species composition (Moffett et al., 1997).

\subsection{Oceanic areas}

Atmospheric inputs of fixed nitrogen can probably only directly affect waters that at least seasonally show nutrient depletion. HNLC regions such as the Southern Ocean will not respond directly to atmospheric nitrogen inputs since there is already excess nitrate in the water column. Atmospheric nitrogen inputs to these regions are modest (Galloway et al., 2004) anyway and may contribute in a small way to the concentrations in deepwater when water masses in this region sink. Atmospheric iron inputs in such regions although small may of course be very important (Jickells et al., 2005). Hence in considering atmospheric nitrogen inputs it is simplest to really only consider the central gyre regions and the temperate ocean waters subject to seasonal macro nutrient depletion. Primary production in these waters is clearly nutrient limited, though not necessarily limited by nitrogen supply or at least not only by nitrogen supply (e.g. Mills et al., 2004). Baker et al., (2003 and in press) consider the balance of atmospheric nutrient supply through the Atlantic Ocean, demonstrating that the aerosol is a very minor source of phosphorus and silicon compared to its role supplying iron. Furthermore meteorological processes mean that atmospheric inputs of $\mathrm{Fe}$ and $\mathrm{N}$ are co-located over the tropical Atlantic (Baker et al., in press). A similar situation probably occurs in the Pacific Ocean as the Asian dust plume passes over the industrial zone of China, Japan and Korea. (Galloway et al., 2004; Jickells et al., 2005), an area likely to see large increases in nitrogen flux in coming decades with increasing industrialisation in this region (Galloway et al., 2004) and this has already been documented for $\mathrm{NO}_{2}$ using satellites (Richter et al., 2005). Note the co-deposition of nitrogen and iron is not always the case, with, for example, the major nitrogen plume from the northern United States not being associated with significant dust transport. Given the minor role of silicon as a nutrient in ocean gyre regions, co-deposition of nitrogen and iron translates into the atmospheric input pushing the system toward phophorus limitation, both by supplying inputs with a high N/P ratio and supplying Fe which can stimulate nitrogen fixation. The same situation has been argued to occur in the Mediterranean and contribute to the situation of extreme oligotrophy seen in the eastern Mediterranean (Carbo et al., 2005). This means, ironically, that the small atmospheric phosphorus flux may be relatively important compared to the much higher (in absolute and Redfield ratio terms) atmospheric nitrogen flux.

In considering the effects of atmospheric inputs on marine systems, it is obvious that the effects will vary from place to place depending on the gradients in atmospheric nitrogen inputs, the ambient water column nitrogen concentrations and the nitrogen requirements of the euphotic zone community. Impacts may take many forms but the easiest question to
Table 4. Atmospheric nitrogen inputs vs. new primary production for the Sargasso Sea.

\begin{tabular}{ll}
\hline Sargasso Sea Annual Budget & $\mathrm{mmol} \mathrm{Nm}^{-2} \mathrm{yr}^{-1}$ \\
\hline New Production & $670-780^{*}$ \\
Atmospheric Input (wet) & $5.8-29 * *$ \\
\hline & *Jenkins and Doney (2003); ** Knap et al. (1986)
\end{tabular}

pose is whether the atmospheric inputs are going to significantly modify primary productivity and hence potentially have ecological consequences. One way to address this is to consider the situation in the Sargasso Sea near Bermuda (Table 4). This is a relatively oligotrophic gyre region which at least for significant periods of time receives relatively high nitrogen inputs arising from the continental USA (Galloway et al., 1996), and hence is an area where impacts are relatively likely to occur, if anywhere. This implicitly assumes that the system is nitrogen limited whereas in fact it may be phosphorus limited (Wu et al., 2000) or show complex patterns with different nutrient limitation of different communities (e.g. Mills et al., 2004). Only long term wet deposition data are available for the Bermuda site and hence total nitrogen deposition will probably be $30 \%$ higher based on Table 3. It is clear from Table 4 that atmospheric inputs, with or without dry deposition, are small compared to "new" primary production and hence large scale impacts are unlikely. Sources of nitrogen to sustain new production at this site have been extensively discussed (e.g. Jenkins and Doney, 2003).

Although this calculation specifically implies that the impacts of atmospheric deposition are likely to be small, this is not the only way to consider the impacts of atmospheric inputs in this area and more generally.

Atmospheric inputs are episodic as noted earlier. Michaels et al. (1993) therefore carefully evaluated if individual atmospheric deposition events could significantly alter primary and new production in the Sargasso Sea. They concluded that this was very unlikely and that ambient water column nitrogen cycling rates and standing stocks are large compared to atmospheric inputs, even on the short term and even allowing for seasonality at this site. Bange et al. (2000) used cruise data on aerosol nitrogen concentrations to estimate the relative importance of atmospheric inputs in sustaining new production in the Northwestern Indian Ocean. They estimate atmospheric deposition rates approximately half those in Table 4 and estimate that atmospheric nitrogen could support $0.1-17 \%$ of new primary production, the range covering different times and areas within the region.

Pahlow and Riebesell (2000) have reported temporal trends in deep ocean Redfield ratios with increasing N/P ratios in the deep waters of the North Atlantic from the 1960s to the 1990s which they suggest could be the result 
Table 5. Estimation of the fertilisation effects on $\mathrm{CO}_{2}$ uptake of anthropogenic nitrogen deposition on the oceans.

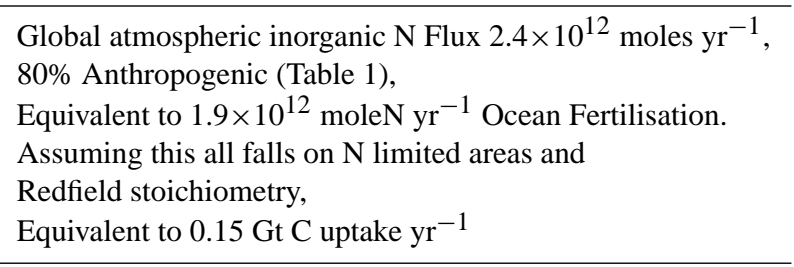

of atmospheric nitrogen deposition. This effect would allow long term impacts of atmospheric nitrogen deposition far from areas of deposition as deepwater returns to the surface at high latitude. The required atmospheric fluxes to modify deep water Redfield ratios are at the upper end of those in Table 4, but it is clear that atmospheric inputs could be contributing to the trend reported. However, Pahlow and Riebesell (2000) do specifically assume the North Atlantic to be nitrogen limited, which as noted earlier may not be the case. They also in their analysis eliminate changes in circulation as a potential cause of the changes seen, but this conclusion may require reconsideration in the light of recent evidence of changes in circulation pathways in this region (Bryden et al., 2005).

An alternative coupling of the iron and nitrogen cycles involves stimulation of nitrogen fixation, since iron is a key nutrient for nitrogen fixing enzymes (Capone et al., 2005; Jickells et al., 2005; Mills et al., 2004). The role of nitrogen fixation will be dealt with elsewhere in this special volume, but it should be noted that dust inputs to the tropical North Atlantic are at a maximum in summer when nutrient conditions in surface waters are most oligotrophic, although there is no direct evidence that this dust input affects $\mathrm{C}$ and $\mathrm{N}$ fluxes to the deep ocean in this region (Jickells et al., 1998). Galloway et al. (1996) suggest that nitrogen fixation is the dominant external input of nitrogen to the North Atlantic. Pahlow and Riebesell (2000) attribute changes in deep water Redfield ratios in the Pacific to changes in atmospheric iron (dust) input to an iron limited ecosystem.

This consideration of the Sargasso Sea region leads to the same conclusion as Michaels et al. (1993), that atmospheric nitrogen inputs are small compared to internal nutrient stocks and cycles within the euphotic zone under most conditions. This region is a central ocean gyre region of rather low ambient water column nutrient concentrations downwind of large atmospheric emissions and if the direct impacts of atmospheric inputs are modest in this region then they will be modest in other areas as well. However, the analysis of Pahlow and Riebesell (2000) points to a different kind of effect, and that is on the larger scale inventory of ocean nitrogen. Atmospheric inputs of nitrogen are comparable to riverine inputs (Galloway et al., 2004) and both can increase the overall stock of nitrogen within the oceans. This nitrogen stock is large so that short term effects of inputs will be modest and hence large scale effects on ocean productivity will be small and may be offset by changes in denitrification. However, it is also possible to consider the atmospheric input as a low level fertilisation effect on the oceans. Hence, in Table 5 I consider the extent to which the atmospheric inputs of nitrogen to the oceans might increase overall new production in the oceans and hence oceanic $\mathrm{CO}_{2}$ uptake. In making this rather preliminary calculation I have assumed that all atmospheric inputs fall into nitrogen limited marine euphotic zone systems. This is clearly not the case and hence the impact is an upper limit. However, most of the major emission regions do in fact pass over nitrogen deficient ocean areas; Galloway et al. (2004) estimate that $85 \%$ of atmospheric deposition to the oceans is into the North Atlantic, North Pacific and Indian oceans, for example. Assuming that all the atmospheric input falls into $\mathrm{N}$ limited waters and stimulates new primary productivity according to Redfield stoichometry implies an increase in ocean productivity equivalent to $0.15 \mathrm{Gt} \mathrm{yr}^{-1} \mathrm{CO}_{2}$ uptake as a result of anthropogenic $\mathrm{N}$ release. This represents 5-10\% of all ocean $\mathrm{CO}_{2}$ uptake and is therefore not trivial in a global sense, though all of the assumptions make this an upper limit, except the exclusion of organic nitrogen. Houghton et al. (1996) reach a broadly similar figure and conclusion.

\subsection{Coastal systems}

Atmospheric deposition rates of nutrients including nitrogen and contaminants are in general higher into coastal waters than to open ocean areas because these are closer to sources. However, the magnitude of atmospheric fluxes varies over at least two orders of magnitude (Jickells, 2005) between relatively pristine environments such as the Alaskan Shelf $\left(0.9 \mathrm{mmol} \mathrm{N} \mathrm{m}^{-2} \mathrm{yr}^{-1}\right)$ to areas close to major centres of habitation and industrial activity (e.g. North Sea $70 \mathrm{mmol} \mathrm{N} \mathrm{m}^{-2} \mathrm{yr}^{-1}$ ). These are annual averages and again it should be stressed that short term events can yield much higher fluxes, and sub-regions of a large area like the North Sea may receive higher fluxes.

There are some additional complications in coastal areas. The higher ammonia concentrations in the atmosphere and complex ammonia cycling in the atmosphere and nutrient rich waters mean that air-sea exchange fluxes for ammonia can be particularly complex (Walker et al., 2004; Sørenson et al., 2004). In addition the seasalt/nitric acid reactions (see earlier) take place as the terrestrial and marine air masses mix (Spokes and Jickells, 2005). Air sea exchange of reactive gases such as ammonia is dependent on small-scale meteorological phenomena. Rapid changes in surface roughness and complex coastal topography make the coastal zone particularly complex meteorologically with the formation of jets, seabreezes etc. (Žager et al., 2005) which means that the whole coastal zone needs to be treated as a complex intermediate zone both physically and chemically, and not as either 
an extension of the terrestrial or oceanic ocean/atmosphere system.

Assessing the impacts of atmospheric deposition to coastal waters is complicated by the importance of other inputs such as rivers and groundwater (Jickells, 1998, 2005; Paerl et al., 2002). These are not completely independent because a significant component of the fluvial nitrogen input may be derived from atmospheric inputs to the catchment. This issue is particularly important in regions with relatively small estuaries compared to their catchment area and hence where direct atmospheric deposition to the estuary is inevitably small (Valigura et al., 2001). For instance, the contribution of atmospheric inputs to the total fluvial nitrogen input ranges from 7-61\% for 34 estuaries on the US east and gulf coasts (Castro et al., 2001), and in most of these estuaries direct atmospheric deposition makes a secondary contribution to the total atmospheric deposition, the proportion being related to the estuarine area versus the watershed area (Castro et al., 2001). Spokes and Jickells (2005) show that for the major North Sea rivers, atmospheric deposition may contribute $15-20 \%$ of total fluvial nitrogen. The importance of atmospheric deposition to river catchments as a contribution to eutrophication pressures leads to the concept of "airsheds", areas where atmospheric emissions influence a coastal water body (Paerl et al., 2002). These airsheds can be 15-200 times larger than the watershed, creating complex challenges for strategies for management of coastal eutrophication.

In the case of large coastal seas such as the North Sea and the Baltic, direct atmospheric deposition to marine waters is also important. For instance, Brion et al. (2004) estimate that atmospheric inputs exceed riverine inputs of nitrogen to the North Sea (1631 vs. $805 \mathrm{kTN} \mathrm{yr}^{-1}$ ), although their atmospheric input estimate is substantially high than that of Rendell et al. (1993) based on direct measurements $\left(412 \mathrm{kTN} \mathrm{yr}^{-1}\right)$, which is similar to the estimate of Rodhe et al. (2005) $350 \mathrm{kTN} \mathrm{yr}^{-1}$, perhaps emphasising the uncertainties in these estimates. Both Brion et al (2004) and Rodhe et al. (2005) agree that the biggest input of $\mathrm{N}$ to the North Sea is from offshore (6476 and $3619 \mathrm{kTn} \mathrm{yr}^{-1}$, respectively) although this value is probably the most uncertain and most difficult to estimate in any budget. In the Baltic Sea, Voss et al. (2005 and references therein) estimate atmospheric $\mathrm{N}$ inputs at $185 \mathrm{kTN} \mathrm{yr}^{-1}$ compared to riverine inputs of 830 $\mathrm{kTN} \mathrm{yr}^{-1}$. Exchanges with the North Sea in this case are also significant sources of N (e.g. Spokes et al., 2005) and for the Baltic Sea in particular nitrogen fixation is also very important (Voss et al., 2005). Direct atmospheric inputs are also important in other areas such a the East China Sea where Zhang and Liu (1994) estimate atmospheric (inorganic) nitrogen inputs to be 1.8 times fluvial inputs and 2 times for $\mathrm{P}$, although fluvial fluxes dominated for Si.

Thus atmospheric nitrogen sources are clearly significant compared to other terrestrial nitrogen sources, and as noted earlier these inputs have been significantly increased by human impact. However, assessing the impact of atmospheric inputs does require that other inputs, such as those from offshore and from nitrogen fixation are considered. In addition different responses can be anticipated from different coastal biogeochemical communities in response to nutrient loadings depending on the hydrography of each coastal area (e.g. Jickells, 1998; Paerl et al., 2002). Hence it is very difficult to generalise except to the extent that primary productivity in many most coastal waters is nitrogen limited (Jickells 1998; Paerl et al., 2002), and hence any input of nitrogen will enhance productivity.

Pearl (1995) has shown that atmospheric inputs can represent a significant component of external inputs of nitrogen to a wide variety of systems and (Paerl, 2002) has shown that atmospheric deposition at high but plausible concentrations can alter productivity. Paerl (2002) and Paerl et al. (2002) also showed that supplying the nitrogen in different forms can alter the phytoplankton response.

Spokes and Jickells (2005) have considered various strategies to assess the significance of atmospheric nitrogen inputs. They point out that budget approaches which indicate the relative importance of atmospheric nitrogen inputs may not on their own always be the most appropriate method to assess the impact of atmospheric deposition on primary productivity. Thus as noted already for offshore waters, much of the primary productivity in coastal waters is sustained by internal recycling on a variety of time scales. Hence atmospheric (and indeed other) inputs may be small compared to productivity requirements for nitrogen and in the short term standing stocks of phytoplankton, bloom development and primary production may not be affected by atmospheric deposition events. However, atmospheric inputs do increase standing stocks of nitrogen and in this way contribute to the overall magnitude of algal activity. In addition, while atmospheric deposition events may usually not be large enough to stimulate blooms, they may play an important role in sustaining them (e.g. Kononen, 2001).

In a detailed study of the role of nitrogen deposition in the Kattegat, Spokes et al. (2005) showed again that atmospheric inputs were only a small part of the overall nitrogen cycle, although their relative importance changed seasonally. Hence rainfall in summer to nutrient depleted areas is likely to have more impact than inputs in winter to temperate waters with high nutrient concentration and light limitation. On their own, atmospheric inputs were unlikely to stimulate blooms but again can contribute to the overall eutrophication pressure in the area. These authors went on to evaluate management options for reducing nitrogen loading and associated eutrophication pressures noting that different strategies were required for ammonia/ammonium and nitric acid/nitrate because of their different sources and deposition characteristics. Thus local regulation would be most effective for ammonia/ammonium while regional strategies would be required for nitric acid/nitrate and since both were important, large scale integrated management strategies would be needed. The results of Valigura et al. (2001) for the eastern 
United States are similar and suggest this is a general conclusion on management strategies. The scale of airsheds (Paerl et al., 2002) requires that management strategies for coastal eutrophication must consider management of agricultural and combustion based emissions of nitrogen throughout the air shed and watershed.

\section{Conclusions}

Atmospheric nitrogen inputs to the oceans are comparable in magnitude to riverine inputs on a global basis and thus an important part of the global nitrogen budget. These fluxes have also been greatly perturbed by human activity. In general atmospheric nitrogen inputs are small compared to internal ocean nitrogen fluxes and so are unlikely to cause large scale changes in phytoplankton activity. However, such changes are locally possible under special circumstances and atmospheric nitrogen inputs do contribute to the productivity of the oceans and coastal waters.

Acknowledgements. I thank the organisers of the SPOTON meeting for stimulating me to this review and I thank all my present and past colleagues whose papers and thinking I have absorbed, particularly my long term collaborator L. Spokes.

Edited by: S. W. A. Naqvi

\section{References}

Ayers, G. P., Gillett, R. W., Cainey, J. M., and Dick, A. L.: Chloride and bromide loss from sea-salt particles in Southern Ocean air, J. Atmos. Chem., 33, 299-319, 1999.

Baker, A. R., Kelly, S. D. Biswas, K. F. Witt, M., and Jickells, T. D.: Atmospheric deposition of nutrients to the Atlantic Ocean, Geophys. Res. Lett., 30, 2296, doi:10.1029/2003GL018518/, 2003

Baker, A. R., Jickells, T. D., Biswas, K. F., Weston, K., and French, M.: Atmospheric aerosols along the AMT transect - sources and cycling of atmospheric nutrients, Deep-Sea Res. II, in press, 2006.

Bigg, G. R., Jickells, T. D., Liss, P. S., and Osborn, T. J.: The Role of the Oceans in Climate, Int. J. Climatol., 23, 1127-1159, 2003.

Brion, N., Baeyens, W., De Galan, S., Elskens, E., and Laane, W. P. M.: The North Sea: source or sink for nitrogen and phosphorus to the Atlantic Ocean, Biogeochem., 68, 277-296, 2004.

Bryden, H. L., Longworth, H. R., and Cunningham, S. A.: Slowing of the Atlantic meridional overturning circulation at $25^{\circ} \mathrm{N}$, Nature, 438, 655-657, 2005.

Cape, J. N., Anderson, M., Rowland, A. P., and Wilson, D.: Organic nitrogen in precipitation across the United Kingdom, Water Air \& Soil Pollut. Focus, 4, 25-35, 2004.

Capone, D. G., Burns, J. A., Montyoa, J. P., Subramaniam, A., Mahaffey, C., Gunderson, T., Micheals, A. F., and Carpenter, E. J.: Nitrogen fixation by Trichodesmium spp: An important source of new nitrogen to the tropical and subtropical North Atlantic Ocean, Global Biogeochem. Cycles, 19, doi: GB20204 10.1029/2004GB002331, 2005.
Carbo, P., Krom, M. D., Homoky, W. B., Benning, L. G., and Herut, B.: Impact of atmospheric deposition on $\mathrm{N}$ and $\mathrm{P}$ geochemistry in the southwestern Levantine basin, Deep-Sea Res. II, 52, 30413053, 2005.

Carstensen, J., Frohn, L. M., Hasager, C. B., and Gustafsson, B. G.: Summer algal blooms in a coastal ecosystem: the role of atmospheric deposition versus entrainment fluxes, Est. Coastal Shelf Sci., 62, 595-608, 2005.

Castro, M. S., Driscoll, C. T., Jordan, T. E., Reay, W. G., Boynton, W. R., Seitzinger, S. P., Styles, R. V., and Cable, J. E.: Contribution of atmospheric deposition to the nitrogen loads to thirty four estuaries on the Atlantic and Gulf coasts of the United States, in: Nitrogen Loading in Coastal Water Bodies: An atmospheric Perspective, Valigura, R. A., Alexander, R. B., Castro, M. S., Meyers, T. P., Paerl, H. W., Stacey, P. E., and Turner, R. E., 77-106, AGU, 254 pp., 2001.

Chester, R., Bradshaw, G. F., Ottley, C. J., Harrison, R. M., Merrett, J. L., Preston, M. R., Rendell, A. R., Kane, M. M., and Jickells, T. D.: The atmospheric distributions of trace metals, trace organics and nitrogen species over the North Sea, in: Understanding the North Sea System, 165-178, edidted by: Charnock, H., Dyer, K. R., Huthnance, J. M., Liss, P. S., Simpson, J. H., and Tett, P. B., Chapman Hall, 222 pp, 1994.

Cornell, S., Mace, K., Coeppicus, S., Duce, R., Huebert, B., Jickells, T., and Zhuang, L. Z.: Organic nitrogen in Hawaiian rain and aerosol, J. Geophy. Res., 106, 7973-7983, 2001.

Cornell, S. E., Jickells, T. D., Cape, J. N., Rowland, A. P., and Duce, R. A.: Organic nitrogen deposition on land and coastal environments: a review of methods and data, Atmos. Environ., 37, 2173-2191, 2003.

Duce, R. A., Liss, P. S., Merrill, J. T., Atlas, E. L., Buat-Menard, P., Hicks, B. B., Miller, J. M., Prospero, J. M., Arimoto, R., Church, T. M., Ellis, W. E., Galloway, J. N., Hansen, L., Jickells, T. D., Knap, A. H., Reinhardt, K. H., Schneider, B., Soudine, A., Tokos, J. J., Tsunogai, S., Wollast, R., and Zhou, M.: The atmospheric input of trace species to the world ocean, Global Biogeochem. Cycles, 5, 193-259, 1991.

Falkowski, P. G., Barberm, R. T., and Smetacek, V.: Biogeochemical controls and feedbacks on ocean primary production, Science, 281, 200-206, 1998.

Galloway, J. N., Dentener, F. J. Capone, D. G., Boyer, E. W., Howarth, R. W. Seitzinger, S. P. Asner, G. P., Cleveland, C. C., Green, P. A., Holland, E. A., Karl, D. M., Michaels, A. F., Porter, J. H., Townsend, A. R., and Vorǒsmarty, C. J.: Nitrogen cycles: past, present and future, Biogeochemistry, 70, 153-226, 2004.

Jenkins, W. J. and Doney, S. C.: The subtropical nutrient spiral, Global Biogeochem. Cycles, 17, 1110, doi:10.1029/2003GB002085, 2003.

Houghton, J. T., Meira Filho, L. G., Callander, B. A., Harris, N., Kattenberg, A., and Maskell, K.: Climate Change 1995, The Science of Climate Change IPCC and Cambridge University Press, 1996.

Huebert, B., Vitouse, P., Sutton, J., Elias, T., Heath, J. Coeppicus, S., Howell, S., and Blonquist, B.: Volcano fixes nitrogen into plant-available forms, Biogeochemistry, 47, 111-118, 1999.

Jickells, T. D.: Nutrient biogeochemistry of the coastal zone, Science, 281, 217-222, 1998.

Jickells, T. D., Dorling, S., Deuser, W. G., Church, T. M., Arimoto, R., and Prospero, J. M.: Air-borne dust fluxes to a deep water 
sediment trap in the Sargasso Sea, Global Biogeochemical Cycles, 12, 311-320, 1998.

Jickells, T. D., Kelly, S. D., Baker, A. R., Biswas, K., Dennis, P. F., Spokes, L. J., Witt, M., and Yeatman, S. G.: Isotopic evidence for a marine ammonia source, Geophys. Res. Lett., 30, doi:10.1029/2002GL016728, 2003.

Jickells, T. D., An, Z. S., Andersen, K. K., Baker, A. R., Bergametti, G., Brooks, N., Cao, J. J., Boyd, P. W., Duce, R. A., Hunter, K. A., Kawahata, H., Kubilay, N., laRoche, J., Liss, P. S., Mahowald, N., Prospero, J. M., Ridgwell, A. J., Tegen, I., and Torres, R.: Global iron connections between desert dust, ocean biogeochemistry and climate, Science, 208, 65-71, 2004.

Kane, M. M., Rendell, A. R., and Jickells, T. D.: Atmospheric scavenging processes over the North Sea, Atmos. Environ., 28, 25232530, 1994.

Keene, W. C., Sander, R., Pszenny, A. A. P., Vogt, R., Crutzen, P. J., and Galloway, J. N.: Aerosol pH in the marine boundary layer: a review and model evaluation, J. Aerosol Sci., 29, 339-356, 1998.

Kelly, S. D., Stein, C., and Jickells, T. D.: Carbon and nitrogen isotopic composition of atmospheric organic matter, Atmos. Environ., 39, 6007-6011, 2005.

Knap, A. H., Jickells, T. D., Pzenny, A., and Galloway, J. N.: Significance of atmosphere derived fixed nitrogen on productivity of the Sargasso Sea, Nature, 320, 158-160, 1986.

Kononen, K.: Eutrophication, harmful algal blooms and species diversity in phytoplankton communities: examples from the Baltic Sea, Ambio, 30, 184-189, 2001.

Liss, P. S. and Galloway, J. N.: Air-sea exchange of sulphur and nitrogen and their interaction in the marine atmosphere, in: Interactions of C, N, P and S Cycles and Global Change, edited by: Wollast, R., Mackenzie, F. T., and Chou, L., Springer, Berlin, 249-281, 1993.

Mace, K. A., Artaxo, P., and Duce, R. A.: Water soluble organic nitrogen in Amazon Basin aerosols during the dry (biomass burning) and wet seasons, J. Geophys. Res., 108, doi:10.1029/2003JD003557, 2003a.

Mace, K. A., Kubilay, N., and Duce, R. A.: Organic nitrogen in rain and aerosol in the eastern Mediterranean atmosphere: An association with atmospheric dust, J. Geophys. Res., 108, doi:10.1029/2002JD003058, 2003b.

Mace, K. A., Duce, R. A., and Tindale, N. W.: Organic nitrogen in rain and aerosol at Cape Grim, Tasmania, Australia, J. Geophys. Res., 108, doi:10.1029/doi10.1029/2002JD003051, 2003c.

Meyers, T., Sickles, J., Dennis, R., Russell, K., Galloway, J., and Church, T.: Atmospheric nitrogen deposition to coastal estuaries and their watersheds, in: Nitrogen Loading in Coastal Water Bodies: An Atmospheric Perspective, edited by: Valigura, R. A., Alexander, R. B., Castro, M. S., Meyers, T. P., Parel, H. W., Stacey, P. E., and Turner, R. E., AGU, 254 pp., 53-76, 2001.

Michaels, A. F., Siegel, D. A., Johnson, R. I., Knap, A. H., and Galloway, J. N.: Episodic inputs of atmospheric nitrogen to the Sargasso Sea: Contributions to new production and phytoplankton blooms, Global Biogeochem. Cycles, 7, 339-351, 1993.

Mills, M. M., Ridame, C., Davey, M., laRoche, J., and Geider, R. J.: Iron and phosphorus co-limit nitrogen fixation in the eastern tropical North Atlantic, Nature, 429, 292-294, 2004.

Moffett, J. W., Brand, L. E., Croot, P. L., and Barbeau, K. A.: Cu speciation and cyanobacterial distributions in harbors subject to anthropogenic Cu inputs, Limnol. Oceanogr., 42, 789-799, 1997.
Neff, J. C., Holland, E. A., Dentener, F. J., McDowell, W. H., and Russell, K. H.: The origin, composition and rates of organic nitrogen deposition: a missing piece of the nitrogen cycle, Biogeochem., 57/58, 99-136, 2002.

NEGTAP: Transboundary Air Pollution: Acidification, Eutrophication and Ground-level Ozone in the UK. DEFRA UK, 2001.

Norman, M. and Leck, C.: Distribution of marine boundary layer ammonia over the Atlantic and Indian Oceans during the Aerosols99 cruise, J. Geophys. Res., 110, doi:10.1029/2005JD005866, 2005.

Pahlow, M. and Riebesell, U.: Temporal trends in deep ocean Redfield ratios, Science, 287, 831-833, 2000.

Paerl, H. W.: Coastal eutrophication in relation to atmospheric nitrogen deposition: current perspectives, Ophelia, 41, 237-259, 1995.

Paerl, H. W.: Connecting atmospheric nitrogen deposition to coastal eutrophication, Environ. Sci. Technol., 36, 323A-326A, 2002.

Paerl, H. W., Dennis, R. L., and Whitall, D. R.: Atmospheric deposition of nitrogen: implications for nutrient over-enrichment of coastal waters, Estuaries, 25, 677-693, 2002.

Pahlow, M. and Riebesell, U.: Temporal trend in deep ocean Redfield ratios, Science, 287, 831-833, 2000.

Pryor, S. C. and Sørenson, L. L.: Dry deposition of reactive nitrogen to marine environments: recent advances and remaining uncertainties, Mar. Pollut. Bull., 44, 1177-1181, 2002.

Raes, F., van Dingenen, R., Vignati, E., Wilson, J., Putaud, J.-P., Seinfeld, J. H., and Adams, P.: Formation and cycling of aerosols in the global troposphere, Atmos. Environ., 34, 4215-4240, 2000.

Rendell, A. R., Ottley, C. J., Jickells, T. D., and Harrison, R. M.: The atmospheric input of nitrogen to the North Sea, Tellus, 45B, 53-63, 1993.

Richter, A., Burrows, J., Nüss, P. H., Granier, C., and Niemeyer, U.: Increase in tropospheric nitrogen dioxide over China from space, Nature, 437, 129-132, 2005.

Rodhe, J., Tett, P., and Wulff, F.: The Baltic and North seas: a regional review of some important physical-chemical-biological interaction processes, in: The Seas, edited by: Robinson, A. and Brink, K., Harvard University Press, 14, Chapter 26, 2005.

Russell, K. M., Keene, W. C., Maben, J. R., Galloway, J. N., and Moody, J. L.: Phase partitioning and dry deposition of atmospheric nitrogen at the mid-Atlantic coast, J. Geophys. Res., 108, doi:10.1029/2003JD003736, 2003.

Seinfeld, J. H. and Pandis, S. N.: Atmospheric Chemistry And Physics: From Air Pollution To Global Climate Change, Wiley, New York, 1325 pp, 1998.

Seitzinger, S. P. and Sanders, R. W.: Atmsopheric inputs of organic nitrogen stimulate estuarine bacteria and phytoplankton, Limnol. Oceanogr., 44, 721-730, 1999.

Sørenson, L. L., Hertel, O., Skjøth, C. A., Lund, M., and Pedersen, B.: Fluxes of ammonia in the coastal marine boundary layer, Atmos. Environ., 37, Supplement No. 1, S167-S177, 2003.

Spokes, L. J. and Jickells, T. D.: Is the atmosphere really an important source of reactive nitrogen to coastal waters?, Cont. Shelf Res., 25, 2022-2035, 2005.

Spokes, L., Jickells T., Weston, K., Gustafsson, B. G., Johnsson M. Liljebladh, B., Conley, D. Ambelas-Skjødth, C. Brandt, J. Carstensen, J. Christiansen, T. Frohn, L., Geernaert, G., Hertel, O., Jensen, B., Lundsgaard, C Markager, S. Martinsen W., Møller, B., Pedersen B., Sauerberg, K., Sørensen, L. L., Hasager, 
C. C., Sempreviva, A. M., Pryor, S. C., Lund, S. W., Larsen, S., Tjernström, M., Svensson, G., and Žagar, M.: MEAD - An interdiciplinary study of the effects of atmospheric deposition in the Kattegat, Environ. Pollut., 140, 453-462, 2005.

Valigura, R. A., Alexander, R. B., Castro, M. S., Meyers, T. P., Paerl, H. W., Stacey, P. E., and Turner, R. E. (Eds.): Nitrogen Loading in Coastal Water Bodies: An atmospheric Perspective, AGU, 254 pp, 2001.

Voss, M., Emeis, K.-C., Hille, S., Neumann, T., and Dipner, J. W.: Nitrogen cycle of the Baltic Sea from an isotopic perspective, Global Biogeochem. Cycles, 19, doi:10.1029/2004GB002338, 2005 .
Walker, J. T., Whitall, D. R., Robarge, W., and Paerl, H. W.: Ambient ammonia and ammonium aerosol across a region of variable emission density, Atmos. Environ., 38, 1235-1246, 2004.

Wu, J., Sunda, W., Boyle, E. A., and Karl, D. M.: Phosphate depletion in the western north Atlantic Ocean, Science, 289, 759-762, 2000.

Žagar, M., Svensson, G., and Tjernström, M.: High spatial and temporal variabilty of dry deposition in a coastal region, Environmental Fluid Mechanics, 5, 357-372, 2005.

Zhang, J. and Liu, M. G.: Observations on nutrients and sulphate in atmospheric wet deposition over the northwest Pacific coastal oceans - Yellow Sea, Mar. Chem., 47, 173-189, 1994. 